Bangl. J. Vet. Med. (2008). 6 (2): 217-221

\title{
PHYSICAL AND MICROBIAL QUALITIES OF RAW MILK COLLECTED FROM BANGLADESH AGRICULTURAL UNIVERSITY DAIRY FARM AND THE SURROUNDING VILLAGES
}

\author{
M. T. G. Khan, M. A. Zinnah, M. P. Siddique*, M. H. A. Rashid ${ }^{1}$, M. A. Islam and K. A. Choudhury \\ Department of Microbiology and Hygiene, ${ }^{1}$ Department of Physiology, Faculty of Veterinary Science, \\ Bangladesh Agricultural University, Mymensingh-2202, Bangladesh \\ *Corresponding author’s e-mail address: mpsiddique77@gmail.com
}

\begin{abstract}
The present study was undertaken with the aim of investigating the physical parameters (e.g. organoleptic and specific gravity of raw milk) and also to study the microbiological quality of raw milk (total viable count, Coliform count and Staphylococcal count) from different villages and Bangladesh Agricultural University (BAU) Dairy Farm of Mymensingh District of Bangladesh, during the period from July to November 2007. A total number of 100 raw milk samples were collected at morning and evening from BAU dairy farm and surrounding four villages of BAU campus. The organoleptic and bacteriological qualities of each sample were analyzed. The organoleptic examination included taste panel score to assess consumer's acceptance and the bacteriological analysis comprised enumeration of total viable count (TVC), total colifrom count (TCC) and total staphylococcal count (TSC) for the determination of sanitary quality. The organoleptic quality of the milk samples is more or less same except the Churkhai milk samples which had flat taste (in 16\% milk sample). The average values of TVC/ml were log 5.920, 5.934, 6.007, 6.075 and 6.127 for BAU Dairy Farm, Boira, Shutiakhali, Churkahai and Paglabazar respectively; coliform count were $\log 2.501$, 2.522, 2.550, 2.620 and 2.619 respectively; staphylococcal count were $\log 2.832,2.812,2.866,2.931$ and 2.988 respectively. So, it may be concluded that the raw milk samples of BAU Dairy Farm were superior to others collected from the selected villages which may be due to maintaining better hygienic condition.
\end{abstract}

Key words: Raw milk, physical and microbial quality

\section{INTRODUCTION}

Milk is defined to be the lacteal secretion, practically free from colostrums, obtained by the complete milking of one or more healthy cows, five days after and 15 days before parturition, which contains not less than 8.5 percent milk solids-not-fat and not less than 3.5 percent milk fat (U.S. Public Health Service, 1965; Itzerott, 1960). According to Byron et al. (1974), the average composition of milk are (i) Water (87.20\%), (ii) Protein (3.50\%), (iii) Fat (3.70\%), (iv) Milk sugar or lactose (4.90\%), (v) ash (0.70\%) and (vi) Dry matter (12.80\%). The constituents may vary with breed, type of feed, stage of lactation, season and age of the cow etc. and also between individuals of the same breed.

It is well established that consumers want clean, wholesome and nutritious food that is produced and processed in a sound, sanitary manner and is free from pathogens. For fulfilling consumer's demand, quality milk production is necessary. Quality milk means, the milk which is free from pathogenic bacteria and harmful toxic substances, free from sediment and extraneous substances, of good flavor, with normal composition, adequate in keeping quality and low in bacterial counts. In Bangladesh milk is produced mostly in non-organized way and usually it being supplied to the consumers from the urban and rural areas by Goalas. Although there are little milk pockets specially milk vita and some established dairy farm where surplus milk is readily available but this perishable product has never received particular attention for by hygienic distribution to the consumers. On the other hand, it is also an excellent media for growth of large variety of bacteria. Cousin (1982) reported that there are so many sources viz. udder, body of the cows, litter, floor, flies, insects and rodents, water supply, milker, milk utensils and atmosphere etc. for bacterial contamination of milk. Oliver et al. (2005) reported that milk and milk products derived from milk of dairy cows can harbor a variety of microorganisms and can be important sources of food borne pathogens. So, the present study was undertaken with the aim of investigating the physical parameters (e.g. organoleptic and specific gravity of raw milk) and also to study the microbiological quality of raw milk (total viable count, Coliform count and Staphylococcal count) from different villages and Bangladesh Agricultural University (BAU) Dairy Farm of Mymensingh District of Bangladesh. 


\section{MATERIALS AND METHODS}

\section{Experimental design}

The whole study was conducted at Bacteriology Laboratory under the Department of Microbiology and Hygiene, Faculty of Veterinary Science, BAU, Mymensingh, during the period from July to November 2007. A total number of 100 raw milk samples were collected at morning and evening from BAU dairy farm and surrounding four villages of BAU campus. The organoleptic and bacteriological qualities of each sample were analyzed. The organoleptic examination included taste panel score to assess consumer's acceptance and the bacteriological analysis comprised enumeration of total viable count (TVC), total colifrom count (TCC) and total staphylococcal count (TSC) for the determination of sanitary quality.

\section{Sources, collection and transportation of samples}

Bangladesh Agricultural University Dairy Farm and other four different villages (Boira, Shutiakhali, Churkhai, Paglabazar) surrounding the BAU campus, were selected for collection of milk sample. About $250 \mathrm{ml}$ of individual raw milk samples were collected at morning and evening from each cow. After collection, the samples were transported to the laboratory using ice containing box maintaining sterile condition. Twenty individual samples of raw milk (10 of morning and 10 of evening) were randomly collected from milking cow of each village and dairy farm.

\section{Physical examination of the samples}

Organoleptic test of raw milk was performed visually, nasally and lingually with the help of a panel of expert to determine colour, flavour and texture. Specific gravity was also determined using lactometer.

\section{Taste panel scores}

The organoleptic quality of each raw milk was evaluated by a panel of experts with the help of appearance, texture, smell and taste characteristics as per standard score card (ISO, 1995).

\section{Microbiological examination of samples}

Enumeration of TVC, TCC and TSC: Ten fold dilution of each raw milk sample was prepared using peptone water. For the determination of TVC, $0.1 \mathrm{ml}$ of each dilution was transferred using sterile pipette and spreaded on PC agar using a sterile glass spreader for each sample. The plates were then kept in an incubator at $37^{\circ} \mathrm{C}$ for 24-48 hours. Following incubation, plates exhibiting 30-300 colonies were counted. The average number of colonies in a particular dilution was multiplied by the dilution factor to obtain the TVC. The TVC was expressed as the number of organism of colony forming units per $\mathrm{ml}$ (CFU/ml) of samples according to ISO (1995). TCC and TSC were also determined by following the similar method of TVC count except the agar. In case of TCC, MacConey agar and in case of TSC, manitol salt agar was used.

\section{Gram's staining}

Gram's Method of staining was performed as per the procedures recommendation of Cowan (1985) to study the morphology and staining character of each isolated bacteria.

\section{Statistical Analysis}

All the data obtained during the study were analyzed statistically to find out the level of significance. The analysis of variance was determined by F-test. The mean differences were evaluated at $1 \%$ level of significance by Duncan's New Multiple Range Test.

\section{RESULTS AND DISCUSSION}

\section{Physical parameters}

The physical parameters were studied after collection and sampling of milk from different villages surrounding the BAU campus and BAU Dairy Farm, Mymensingh. Out of 100 samples, 60 samples were found yellowish white, 20 samples were white, 10 samples were light yellowish white and remaining 10 samples were deep yellowish white in colour (Table 1). These findings agreed with the reports of Judkins and Mack (1955) who reported that normal milk has a yellowish white color due to the presence of fat, casein and the presence of small amount of colouring matter. These differences in colour may be due to the differences in nature of feed consumption or the breed of cow or the fat and solid contents of the milk (Eckles et al., 1951). 
Physical and microbial quality of raw milk

Among 100 milk samples 86 had normal flavour, 10 had sweet aroma and 4 had flat flavour (Table 1), similar to the findings of Islam et al. (1984) who reported that the samples those were collected from BAU dairy farm were yellowish white in colour, slightly sweet in taste and normal in flavour and present investigation also recorded flat flavour taste in four milk samples. In this respect Foley et al. (1972) reported that a cowy flavour was found in milk from cows with Ketosis. The texture of raw milk sample was examined before starting the experiment. All the milk samples (100\%) collected from BAU Dairy Farm and from different villages had normal texture (free flowing liquid) except Paglabazar (Table 1). Sixteen milk samples of Paglabazar had thin texture. Thin texture in milk sample of Paglabazar might be due to breed quality of the milking cows or percentage of water in milk.

Table 1. Physical parameters of raw milk samples collected from different sources

\begin{tabular}{|llllll|}
\hline $\begin{array}{l}\text { Physical } \\
\text { Parameters }\end{array}$ & BAUDF & Boira & Shutiakhali & Churkhai & Paglabazar \\
\hline Color & YW 100\% & YW 50\% & YW 84\% & YW 34\% & YW 84\% \\
& DYW 50\% & White 16\% & White 66\% & LYW 16\% \\
Flavor & $\begin{array}{l}\text { Normal 50\% } \\
\text { Sweet aroma 50\% }\end{array}$ & Normal 100\% & Normal 100\% & Normal 84\% & Normal 100\% \\
Texture & Normal* 100\% & Normal 100\% & Normal 100\% & Normal 100\% & Normal 84\% \\
$\begin{array}{l}\text { Specific } \\
\text { gravity** }\end{array}$ & 1.0295 & 1.0279 & 1.0242 & 1.0237 & Thin 16\% \\
\hline
\end{tabular}

BAUDF = Bangladesh Agricultural University Dairy Farm; \% = percent; YW = Yellowish white; DYW = Deep yellowish white; LYW = Light yellowish white; *= free flowing liquid; **= Mean \pm SD (Standard deviation).

The mean and standard deviation of the specific gravity of raw milk samples collected from BAU Dairy Farm, Boira, Shutiakhali, Churkhai and Paglabazar were $1.0295 \pm 0.0015,1.0279 \pm 0.0007,1.0242 \pm 0.0019$, $1.0237 \pm 0.003$ and $1.0296 \pm 0.0009$ respectively (Table 1 ). The specific gravity of milk of BAU dairy farm and Paglaazar were found relatively higher than the milks of other three villages. This might be due to the breed of milking cow and feed consumption. The findings of this study are in agreement with the findings of Ekles et al. (1951) and Islam et al., (1984). The standard specific gravity of normal whole milk varies from 1.0229 to 1.035 with an average of 1.032 (Ekles et al., 1951).

\section{Total viable count}

The average values of TVC/ml were 8,33,333 CFU/ml (log 5.920), 8,60,833 CFU/ml (log 5.934), 10,17,500 CFU/ml (log 6.007), 11.89,083 CFU/ml (log 6.075) and 13,40,50 CFU/ml (log 6.127) for BAU Dairy Farm, Boira, Shutiakhali, Churkahai and Paglabazar respectively (Table 2) . It was found that total viable bacterial count per ml of raw milk collected from Paglabazar were significantly higher $(\mathrm{P}<0.01)$ than the milk samples of other collected areas. In this study it was found that TVC is comparatively higher in milk sample of Paglabazar and lower in the milk sample of BAU Dairy Farm. The variation in TVC of the milk may be due to the hygienic maintenance during milking. The results of this experiment correlate with findings of Iknomov et al. (1956) who reported that the total bacterial counts ranged from 1,70,000 to 9,000,000 per ml of milk depending on milking techniques and cleanliness. The number of bacteria in aseptically drawn milk was 100-92,000 per ml, but infection occurred subsequently from the skin of animals, milkers hands, cow shed and milking utensils. Lee et al. (1983) conducted an experiment in Seoul of Korea and found that the bacterial count in raw milk ranged from $4 \times 10^{6}$ to $2.7 \times 10^{7}$ per $\mathrm{ml}$. 


\section{Total coliform count}

The average values of coliform counts/ml of milk samples collected from BAU Dairy Farm and surrounding four villages (Boira, Shutiakhali, Churkhai, Paglabazar) were 317.375 CFU/ml (log 2.501), 332.75 CFU/ml (log 2.522), 355..50 CFU/ml (log 2.550), 417.25 CFU/ml (log 2.620), 416.25 CFU/ml (log 2.619) respectively (Table 2). Statistically it was found that the count of coliform bacteria per ml of raw milk which was collected from Paglabazar were statistically higher $(\mathrm{P}<0.01)$ than other samples. The results of this investigation are in agreement with the finding of Mutukumira et al. (1996) who found the coliform bacteria $3.2 \times 102$ to $2.3 \times 105$. Saitanu et al. (1996) examined and found that the total coliform count of $<1000 \mathrm{CFU} / \mathrm{ml}$.

\section{Staphylococcal count}

The average values of staphylococcal counts/ml of milk samples collected from BAU Dairy Farm, Boira, Shutiakhali, Churkhai and Paglabazar were $680.50 \mathrm{CFU} / \mathrm{ml}(\log 2.832), 662.975 \mathrm{CFU} / \mathrm{ml}(\log 2.812), 735.00$ CFU/ml (log 2.866), 855.00 CFU/ml (log 2.931), 973.00 CFU/ml (log 2.988) respectively (Table 2).

Table 2. The average value of TVC, TCC and TSC in raw milk of BAU Dairy farm and surrounding villages of BAU campus

\begin{tabular}{|c|c|c|c|c|c|c|c|}
\hline \multirow{2}{*}{$\begin{array}{l}\text { Sources } \\
\text { of } \\
\text { samples }\end{array}$} & \multirow{2}{*}{$\begin{array}{l}\text { No. of } \\
\text { samples } \\
\text { tested }\end{array}$} & \multicolumn{2}{|c|}{ Total viable count/ml } & \multicolumn{2}{|c|}{ Total coliform count $/ \mathrm{ml}$} & \multicolumn{2}{|c|}{ Staphylococcal count $/ \mathrm{ml}$} \\
\hline & & $\mathrm{CFU} / \mathrm{ml}$ & $\log$ & $\mathrm{CFU} / \mathrm{ml}$ & $\log$ & $\mathrm{CFU} / \mathrm{ml}$ & $\log$ \\
\hline $\mathrm{S}_{1}$ & 20 & $8,33,333$ & 5.920 & 317.38 & 2.501 & 680.50 & 2.832 \\
\hline $\mathrm{S}_{2}$ & 20 & $8,60,833$ & 5.934 & 332.75 & 2.522 & 662.98 & 2.821 \\
\hline $\mathrm{S}_{3}$ & 20 & $10,17,500$ & 6.007 & 355.50 & 2.550 & 735.00 & 2.866 \\
\hline $\mathrm{S}_{4}$ & 20 & $11,89,083$ & 6.075 & 417.25 & 2.620 & 855.00 & 2.913 \\
\hline $\mathrm{S}_{5}$ & 20 & $13,40,500$ & 6.127 & 416.25 & 2.619 & 973.00 & 2.988 \\
\hline \multicolumn{2}{|c|}{ Level of significance } & \multicolumn{2}{|l|}{$* *$} & \multicolumn{2}{|c|}{$* *$} & \multicolumn{2}{|c|}{$* *$} \\
\hline
\end{tabular}

**means $\mathrm{p}<0.01$; NS means $\mathrm{p}>0.05$; CFU = Colony Forming Unit; $\mathrm{S}_{1}=$ BAU Dairy Farm; $\mathrm{S}_{2}=$ Boira; $\mathrm{S}_{3}=$ Shutiakhali; $\mathrm{S}_{4}=$ Churkhai; $\mathrm{S}_{5}=$ Paglabazar; $\mathrm{ml}=$ Milliliter.

It was found that the count of staphylococci bacteria per ml of raw milk which was collected form Paglabazar were statistically higher $(\mathrm{p}<0.01)$ than other samples. In this respect Bae and Seung (1992) suggested that the quality of farm water and other hygienic conditions might be responsible for microbial quality of raw milk. It was found that among the milk samples of the collection site, the raw milk of Paglabazar contained higher TVC, TCC and TSC compare to other four areas (Table 2). This difference may be due to lack of hygienic and other sanitary condition during milking.

So, it may be concluded that the raw milk samples of BAU Dairy Farm were superior to other raw milk samples collected from the selected villages may be due to maintaining better hygienic condition.

\section{REFERENCES}

1. Bae IH and Seung JW (1992). Study on the effects of farm water quality on the micro biological quality of raw milks. Korean Journal of Dairy Science 14 (2): 139-147.

2. Byron HW, Arnold HJ and Johan AA (1974). Fundamentals of dairy chemistry. $2^{\text {nd }}$ edn., Westport, Connecticut. The Avi Publishing Company, Inc. pp. 2-8.

3. Cousin MA (1982). Presence and activity of psychrotrophic microorganisms in milk and dairy products: A review. Journal of Food Protection 45: 172-207.

4. Cowan ST (1985). Cowan and Steel's manual for identification of medical bacteria. $2^{\text {nd }}$ edition. Cambridge University press, Cambridge, London. pp. 138-139.

5. Eckles CH, Combs WB and Macy H (1951). Milk and milk products. $4^{\text {th }}$ edn., Mc. Graw Hill Book Company, New York, Toronto, London. 
Physical and microbial quality of raw milk

6. Foley RC, Bath DD, Diokinson EM and Tueker HA (1972). Dairy cattel: principles practices, problems, profits. Lea and Febiger, Philadelphia, USA.

7. Ikonomov L, Lotov I, Todorov D, Tankov G and Dzhurov TS (1956). Bacteriological studies of Hygiene of milk production of Bulgarian cattle Breeding Farms. Dairy Science Abstract 19: 936.

8. Islam MN, Hossain SMI and Mannan AKMA (1984). Studies on the physical parameters and chemical qualities of market milk in Mymensingh town, Bangladesh. Bangladesh Journal of Animal Science 13 (1-2): 52-56.

9. ISO (1995). International Organization for Standardization. Recommendation of the meeting of the ISO of meat and meat products. ISO/TC-34/SC.6. The Netherlands. pp. 10-18.

10. Itzerott G (1960). Notes on milk and indigenous dairy products of Pakistan. Dairy Science Abstracts 22 (3): 7-11

11. Judkins HF and Mack MJ (1955). The principle of dairying. $3^{\text {rd }}$ Rev. Ed., John Wiley and Sons, Inc. New York. p. 31.

12. Lee JT, Park SY, Korea IK and Kin HU (1983). Quality of raw milk in Korea. Korean Journal of Dairy Science 5 (1): 22-28.

13. Mutukumira AN, Feresu SB, Narbhus JA and Abrahamsen RK (1996). Chemical and Microbiological Quality of raw milk produced by small holder farmers in Zimbabwe. Journal of Food Protection 59 (9): 984-987.

14. Oliver SP, Jayarao BM and Almeida RA (2005). Foodborne pathogens in milk and the dairy farm environment: food safety and public health implications. Foodborne Pathogen and Diseases 2 (2): 115-29.

15. Saitanu IA, Chuanchuen KR, Nuanuarsuwan S, Koowatananukul C and Rugkhaw V (1996). Microbiological quality of raw cow milk. Thai Journal of Veterinary Medicine 26(3): 193-214.

16. U.S. Public Health Services, 1965. Grade A Pasteurise milk ordinance, U.S. Department of Public Health Education and Welfare Service, P.I. 